\title{
Foot Switch Device
}

National Cancer Institute

\section{Source}

National Cancer Institute. Foot Switch Device. NCI Thesaurus. Code C50202.

A switch designed to be actuated by foot pressure. 